\title{
The genesis of a lava cave in the Deccan Volcanic Province (Maharashtra, India)
}

\author{
Nikhil R. Pawar ${ }^{*}$, Amod H. Katikar ${ }^{2}$, Sudha Vaddadi ${ }^{3}$, Sumitra H. Shinde ${ }^{4}$, \\ Sharad N. Rajaguru ${ }^{5}$, Sachin V. Joshi ${ }^{6}$, and Sanjay P. Eksambekar ${ }^{7}$ \\ ${ }^{1}$ Department of Geography, Nowrosjee Wadia College, Pune 411001, India \\ ${ }^{2}$ Department of Geography, Sir Parshurambhau College, Pune 411030, India \\ ${ }^{3}$ Geologist (Retd), Formerly with Geological Survey of India, India \\ ${ }^{4}$ Department of Geography, Tilak Maharashtra Vidyapeeth, Navi Mumbai 400614, India \\ ${ }^{5}$ Professor (Retd), Deccan College of Post Graduate and Research Institute, Pune 411006, India \\ ${ }^{6}$ Department of Archaeology, Deccan College of Post Graduate and Research Institute, Pune 411006, India \\ ${ }^{7}$ Phytolith Research Institute, Chinchwad, Pune 411033, India
}

\begin{abstract}
Lava tubes and channels forming lava distributaries have been recognized from different parts of western Deccan Volcanic Province (DVP). Openings of smaller dimension have been documented from the pāhoehoe flows around Pune, in the western DVP. A small lava cave is exposed in Ghoradeshwar hill, near Pune. Detailed field studies of the physical characteristics, structure and morphology of the flows hosting the lava tube has been carried out. This is the first detailed documentation of a lava cave from the DVP. The lava cave occurs in a compound pāhoehoe flow of Karla Formation, characterized by the presence of lobes, toes and small scale features like squeeze-ups. Field observations and measurements reveal that the dimensions of the cave are small, with low roof and a maximum width of $108 \mathrm{~cm}$. The cave morphology along the $20 \mathrm{~m}$ passage varies from circular to semi-circular, with a twilight zone to the north. The gentle micro-topography at Ghoradeshwar controlled the advancement of pāhoehoe lobes and toes within the sheet lobe. The pre-flow gradients towards the north led to the progression of flow from the east, where the cave opening is presently seen. Dimensions and related morphology of the lava cave suggest that it can be best described as a small subcrustal cave formed by draining of an inflated pāhoehoe lava lobe. At Ghoradeshwar, besides the natural lava cave, Buddhist caves carved in pāhoehoe lava flows are also observed, indicating that early man took advantage of the existing openings in pāhoehoe flows and sculpted the caves to suit their requirements.
\end{abstract}

Keywords: Deccan Volcanic Province; speleology; drained lobe; lava cave

Received 14 June 2015; Revised 30 November 2015; Accepted 30 November 2015

Citation: $\quad$ Pawar N.R., Katikar A.H., Vaddadi S., Shinde S.H., Rajaguru S.N., Joshi S.V. and Eksambekar S.P., 2016. The genesis of a lava cave in the Deccan Volcanic Province (Maharashtra, India). International Journal of Speleology, 45 (1), 51-58. Tampa, FL (USA) ISSN 0392-6672 http://dx.doi.org/10.5038/1827-806X.45.1.1935

\section{INTRODUCTION}

The Deccan Volcanic Province (DVP) basalts spread over half a million square kilometres and cover major parts of western, central India and sub-central parts of Peninsular India. The basalts and associated volcanic suite of rocks were emplaced over a time span from 69 to $63 \mathrm{Ma}$, with the major volcanic pulse at 66.9 $\pm 0.2 \mathrm{Ma}$ (Hooper et al., 2010). The bulk of the DVP is made up of pāhoehoe and 'ā'a flows of varying thicknesses $(5-30 \mathrm{~m})$. The stratigraphic classification of the western DVP has been established based on lithological, geochemical and palaeomagnetic studies (Godbole et al., 1996; Subbarao and Hooper, 1988).
The present study area forms a part of western Deccan Volcanic Province (DVP). Considering the thickness (around $1.5 \mathrm{~km}$ ) and the vast areal extent of the DVP, it is concurred that very large volumes of lava were emplaced during this period.

Emplacement of lava over such a large area requires transport of the lava over great distances and that too in a short time span. Studies from active volcanoes in other places suggest that an insulated and thermally efficient lava transport system involving inflated lava sheets, lava tubes and lava channels, can emplace lava flows across great distances. (Keszthelyi and Self, 1998). Identification of a lava transport system and related features is easier in recent and younger 
volcanic terrains but in the highly dissected Palaeocene Deccan volcanic Province (DVP), the task becomes difficult due to rarity of good outcrops. Nonetheless, remnants of lava tubes and channels have been identified from the pāhoehoe flows of western DVP, by various workers (see Thorat, 1996; Sharma and Vaddadi, 1996; Misra, 2002; Duraiswami et al., 2004; Sen et al., 2012). In all these reported occurrences, the lava tubes are filled with solidified lava and display a conspicuous sinuous shape with reddened amygdular basalt forming lateral accretionary levees. Small openings with a flat base, convex top and limited extension, observed in and around Pune, have been described as lava tunnels by earlier workers (see Kulkarni and Gaikwad, 1984 and Phadke and Ghate, 1984). Similar features of small dimension are seen in the hill adjoining Fergusson College, Pune; which are comparable to blister caves described by Grimes (2002).

Lava caves have been reported from modern lava flows and younger volcanic terrains. World over, lava caves that occur in pāhoehoe lava flows are called 'pyroduct' (Coan, 1844) or 'lava tubes and lava tunnels' as these are believed to have been formed by the conduits that drain the lava down slope (Lockwood and Hazlett, 2010). Lava tube caves or pyroducts have been identified from modern lava flows and younger volcanic terrains of Hawaii, Australia, and Korea, etc. The world's largest and deepest lava caves are found in the geologically young Hawaii islands. Some of the more commonly known ones are the Kazumura cave, the Blair cave, the John Martins cave. Lave caves in pāhoehoe flows are also known from Bend, Oregon (Greeley, 1971), Undara volcano, W. Queensland, Australia (Atkinson et al., 1975), Mammoth crater, USA (Waters et al., 1990) and Chyulu hills, Kenya (Simons, 1998), Cheju Island, Korea (Waltham and Park, 2002). Small caves with shallow roofed chambers are reported from Victoria, Australia (Grimes, 2002) and from Hawaii (Halliday, 2002).

The mechanism of formation of lava caves in ancient lava flows can be better interpreted by comparison with modern lava flows. Observations of active lava flows confirm that most pyroducts are formed at the tip of the lava flow by a continual process of advance (moving ahead) and inflation. Inflation and crusting over of channels, as mechanisms in the formation of pyroduct; have been discussed and compared (Kempe et al., 2010; Lockwood and Hazlett, 2010); the inflationary mode being more prevalent. In the inflationary mode, a gas space exists above the internal lava river and hence a cave can form even if the lava does not drain off completely (Kempe et al., 2010). Mode of formation of pyroduct in pāhoehoe flows is dependent on the slope available. On steeper slopes, crusting over of channels lead to formation of pyroducts and on gentler slopes; pyroducts develop beneath inflating crusts (Lockwood and Hazlett, 2010). Pyroducts also formed from partial draining of flow lobes as reported from Kilauea volcano (Peterson and Swanson, 1974; Greeley, 1987; Hon et al., 1994; and Mount Eccles, Victoria (Grimes, 2002). These according to Kempe et al. (2010) could deepen by thermal and mechanical erosion of their floor. Caves formed by draining of lobes and flows below the crust are generally smaller than those formed by roofing of channel (Grimes, 2002; Grimes, 2005) and caves have been designated as sub-crustal caves.

With this background, the present paper attempts to understand the mode of formation of a small lava cave found in the compound pāhoehoe basalt flows exposed in Ghoradeshwar hill near Pune. This is the first reported volcano - speleological work from the DVP.

\section{GEOLOGY}

Ghoradeshwar hill, located in the Pune district, western Maharashtra is an eastward extension of an offshoot ridge from the Sahyadri mountain range and forms interfluves between the Indrayani and Pauna rivers, which drain the northern and southern parts respectively (Fig. 1). On the southern flank of the hill at an elevation of about $790 \mathrm{~m}$, there is a cave opening facing east having a height of $148 \mathrm{~cm}$ and width of $310 \mathrm{~cm}$ (Fig. 1). The hill slopes have a steep gradient with a thin $(0-30 \mathrm{~cm})$ veneer of regolith.

The cave occurs in flows belonging to the Karla Formation of the Lonavala Sub group. The flows of Karla Formation are older than the Diveghat Formation of the Wai Sub group, which has been dated by ${ }^{40} \mathrm{Ar} /{ }^{39} \mathrm{Ar}$, indicating an age range of 66.2 to 65.3 Ma (Hooper et al., 2010). Hence, it is evident that the flows of Karla Formation which host the lava caves predate $66.2 \mathrm{Ma}$, but must be younger than the onset of the DVP eruptions $69 \mathrm{Ma}$.

The Deccan basalts have undergone considerable erosion since their eruption, with major uplift affecting the western Indian margin throughout the Tertiary period (Widdowson, 1997). This uplift and extensive erosion of the Deccan plateau, in the Tertiary times has resulted in the development and evolution of Deccan palaeosurfaces. More recent erosion of the resultant upland plateau with isolated hills and hill ranges has exposed the lava cave. Weathering and solution activity due to seepage of water has modified the caves further.

The pāhoehoe flows are made up of several small flow units/lobes varying in thickness from a few centimetres to a maximum of $5 \mathrm{~m}$. Two compound pāhoehoe flows can be demarcated, based on the presence of a thin, interflow horizon, a red bole (Fig. 2). The lower compound flow is exposed from the base of the hill to about $800 \mathrm{~m}$ above msl. It is a very sparsely phyric flow with more or less rounded vesicles and is highly vesicular and amygdular in nature. A few vesicular units resemble spongy pāhoehoe flow. The cave occurs in the lower flow. At the cave entrance, fine grained, highly vesicular pāhoehoe units are exposed. The upper compound flow is sparsely phyric, massive in nature and jointed. Joint sets trend NW-SE and so do the major fractures. A doleritic dyke, trending NW-SE, occupying one such a fracture, intrudes the lava pile.

The pāhoehoe flows are thus made up of laterally extensive inter-fingering flow units or lobes, resulting in an irregular micro-topography. These flows resemble 


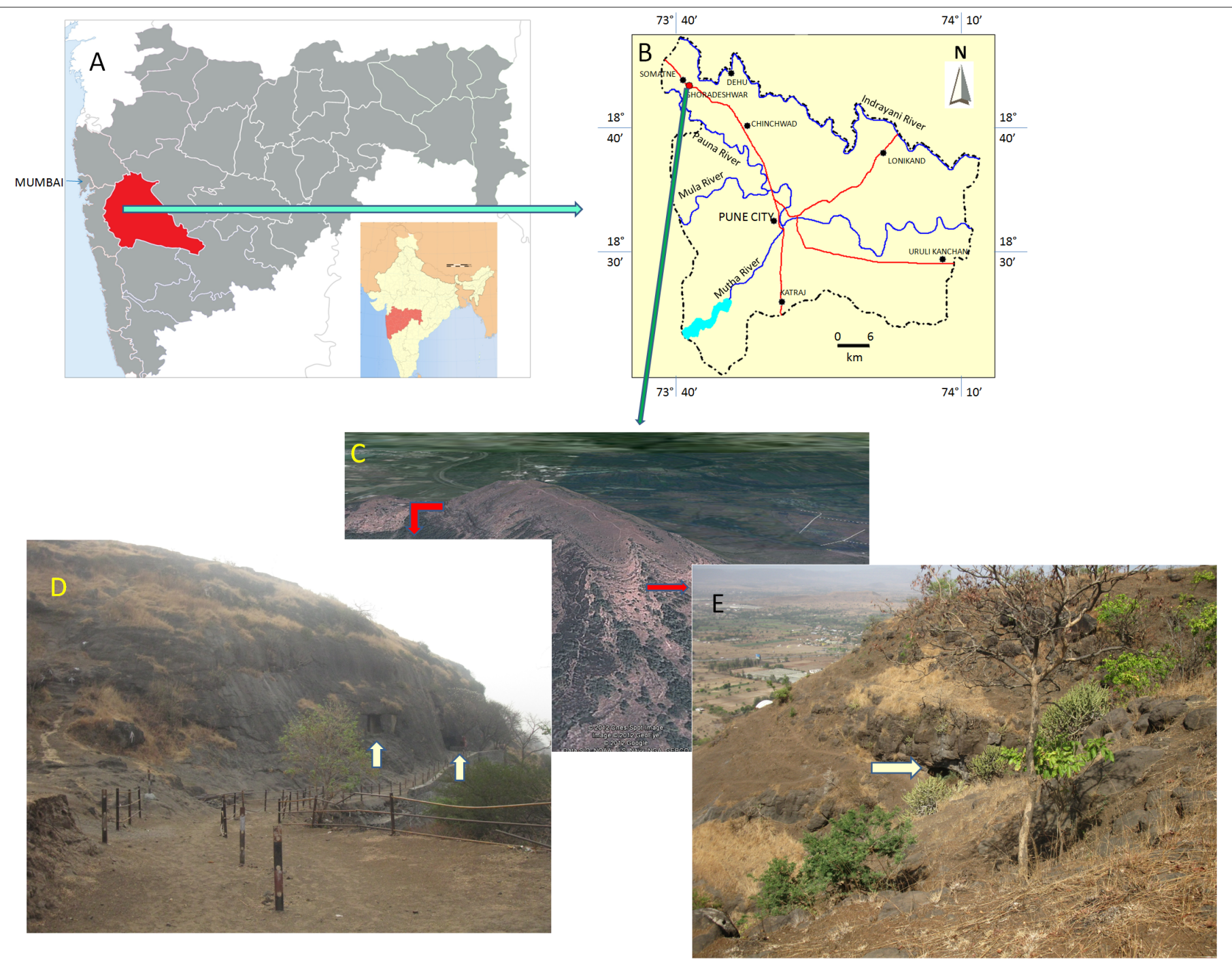

Fig. 1. A) and B) Location map of the study area; C) 3-D view of Ghoradeshwar hill (Google Earth); D) White arrows indicates the location of manmade Buddhist caves towards the south-west side; E) Location of the natural lava cave towards the eastern side.

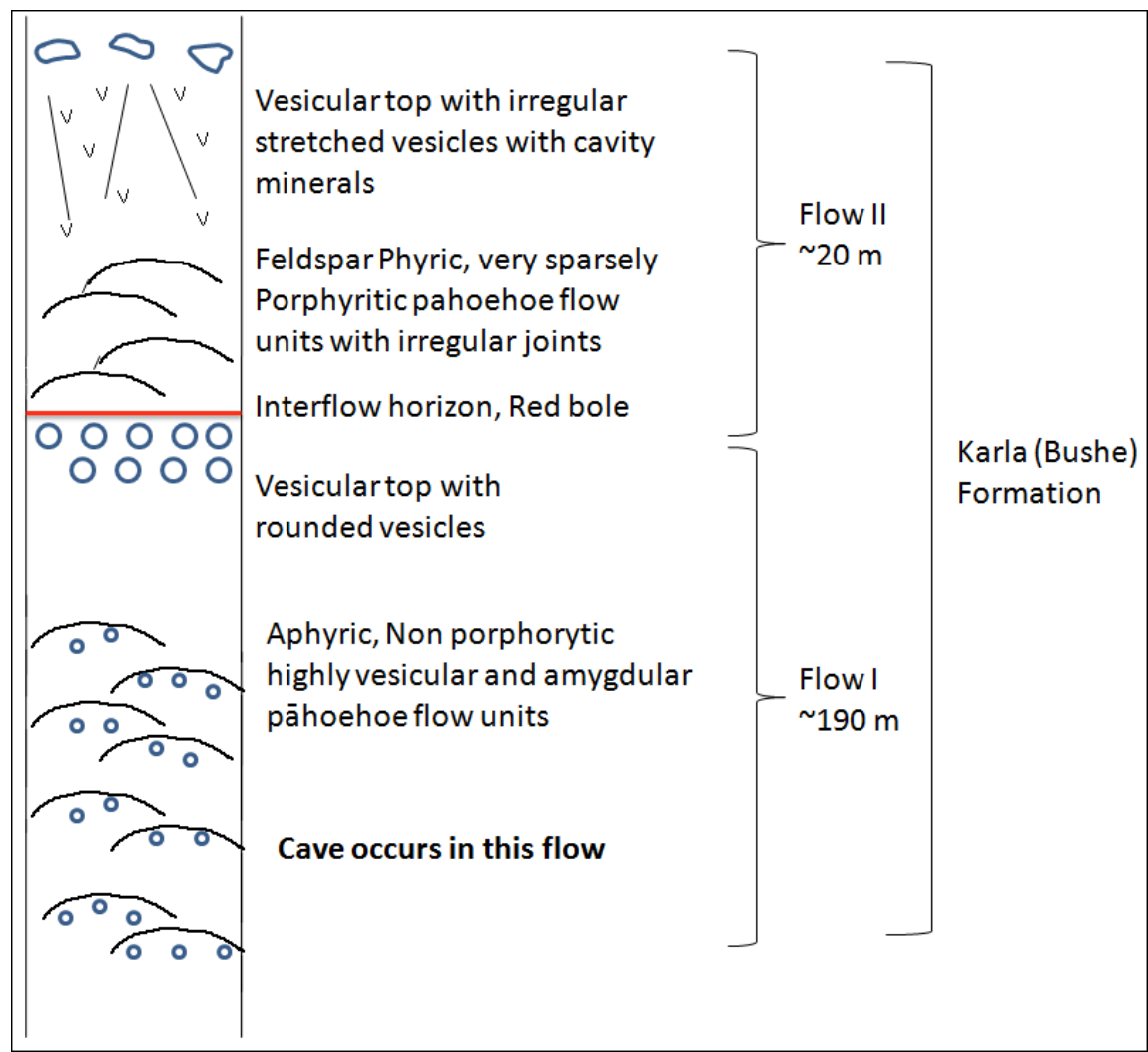

Fig. 2. Litho section of the flows exposed at Ghoradeshwar hill. 
the sheet lobes described by Lockwood and Hazlett (2010). Breakouts leading to smaller pāhoehoe toes are also seen. The individual units are recognized by the presence of pipe amygdales at the base and a zone of spherical vesicles towards the top. Pipe vesicles at the base of the flow units are vertical or inclined. The vesicles in the upper vesicular zone, show alignment, parallel to the flow unit tops. The top surface of the units form reddened glassy crusts due to chilling. Crudely developed ropes and cords are seen on the reddened crust (RC) at places. Vesicle cylinders, indicating escape of stream of volatiles are also seen at places. In a vertical section near the Buddhist cave, four small pāhoehoe flow units can be delineated
(Fig. 3A) clearly. The internal characteristics of the individual flow units indicate endogenous growth by inflation.

Numerous small scale features like squeeze-ups occupying the inflation clefts and connecting the different lobes and units are also seen at places, especially near the Buddhist cave temple (Fig. 3B). This results when the semi-solid lava inside squeezes up through the fractures that have resulted from the stretching of the upper solidified crust. Hence, they generally occur as wedge shaped features interconnecting lobes. The abundance of these features in this area is interesting since it indicates the beginning of growth by sequential lobe-by-lobe emplacement.
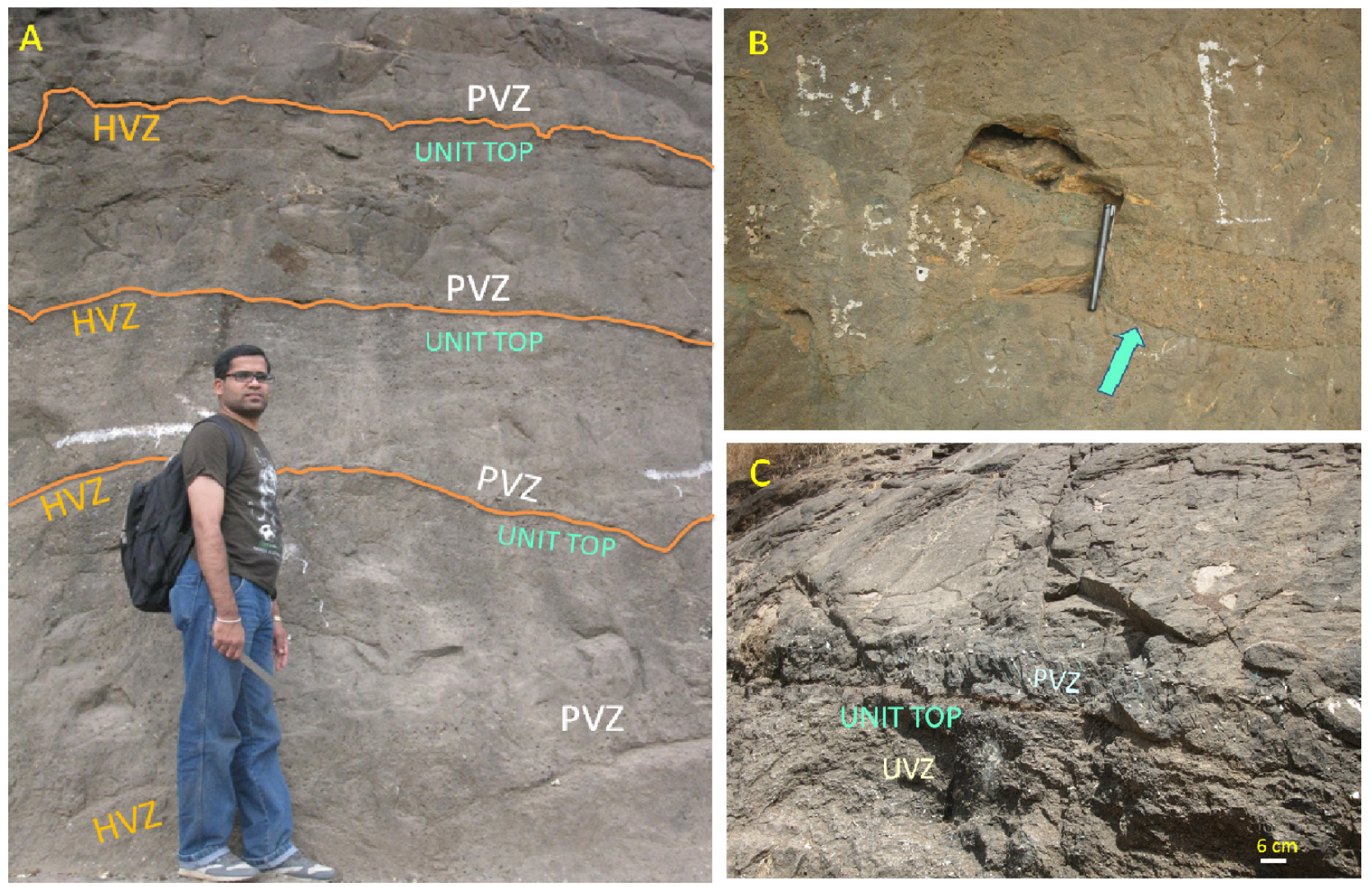

Fig. 3. A) Four flow units in Pāhoehoe (red line marks the reddened crust); B) Squeeze-up (shown by an arrow) in the pāhoehoe flow; length of the pen is $13.5 \mathrm{~cm} ; \mathrm{C}$ ) Close up of the chilled reddened crust marking the unit contact. HVZ- Horizontal Vesicle Zone, UVZ - Upper Vesicular Zone, PVZ- Pipe vesicle zone.

\section{OBSERVATION}

The cave entrance is semi-circular, with a flat floor, which leads into the central part of the cave. This consists of a chamber along with some smaller openings. The gradient of the cave is from southwest to north with total examined passage length of about $20 \mathrm{~m}$. The cross sections in Fig. 4 show the morphological variation along the passage. The passage to the north is nearly circular while the passage to the south-west is semi-circular and oval shaped. The entrance to the passage in the north is large enough for a person to stand. These passages have a twilight zone characterised by decreasing light level. The opening to the north is $113 \mathrm{~cm}$ high and $108 \mathrm{~cm}$ wide, it could be traced for $\sim 12 \mathrm{~m}$, beyond which it tapers and access is only by crawling. Downward erosion or thermal erosion was not observed in the lava cave. The pāhoehoe flow units or lobes exposed in the vicinity of the entrance were highly vesicular and amygdular. The lower flow lobe exposed at the cave entrance is vesicular and amygdular with small spherical vesicles and amygdules. Within the vesicular and amygdular zone a couple of thin (less than a millimetre) light coloured bands are seen, which represent fractures developed parallel to cooling and inflating surface. The roof of the entrance exposes a reddened glassy crust that separates two small flow units or sheet lobes (Fig. 5A). Three seepage points (Fig: 5B) were observed in the narrower south-western passage which is $\sim 8 \mathrm{~m}$ in length. The wall of the cave joins the floor at a right angle. At the top, a curved wall overhangs the passage, while a shelf (Fig. 5C) is observed at the top of the wall. The roof of the cave towards the northern end has an angular gothic shape with a median fracture in the ceiling (Fig. 5D). From the morphological variation along the passage it is evident that the gothic cross section is restricted to only a small portion. 


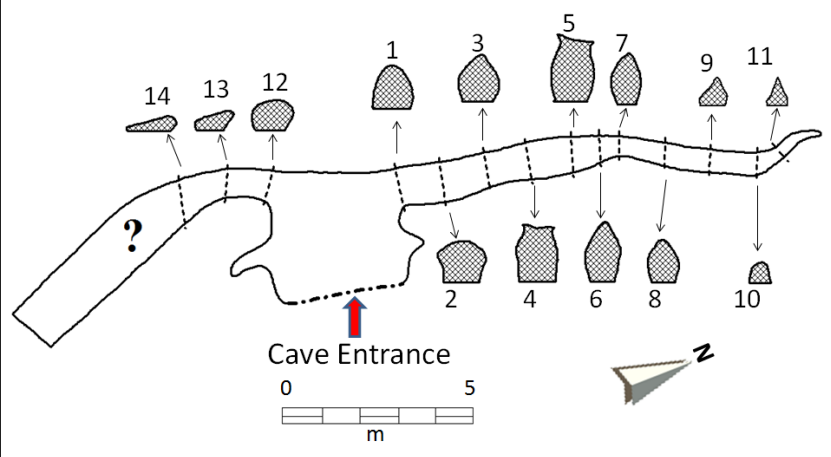

Fig. 4. Ground plan and cross sectional sketch of lava cave at Ghoradeshwar.
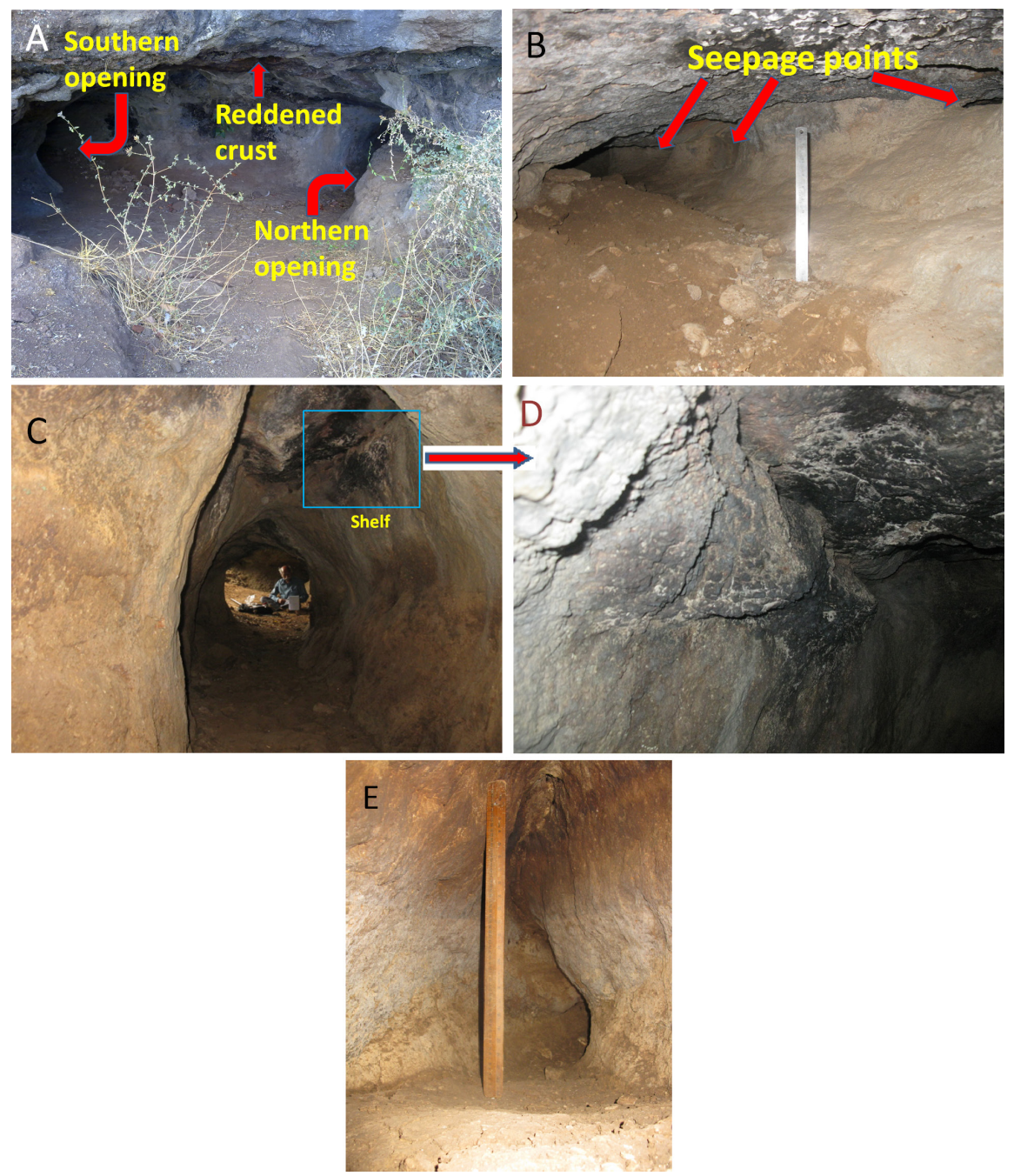

Fig. 5. A) Entrance with central chamber showing the northern and southern opening along with reddened crust; B) Southern passage with seepage points; length of the scale is $30 \mathrm{~cm}$; C) Shelf near the ceiling D) An arrow exhibiting the close up of the shelf; E) Angular gothic shape inside the northern passage; length of the scale is $60 \mathrm{~cm}$.

During the monsoon season infiltration of the rainfall is observed along the seepage points; joint planes and fractures along the ceiling/roof. This water trickles along the sides of the cave as well. This leaves a thin calcium carbonate coating on the cave walls. The water flows towards the northern part, where the cave terminates. As there is no further movement of the water, the accumulation forms a stagnant water body in the cave. On the walls of the cave, water level markings due to slowly receding water level can be clearly observed. During the monsoon, the rate of infiltration is accelerated due to seasonal leaching and the presence of grass and shrub type vegetation on the hilltop (Kale and Kulkarni, 1992; Verachtert et al., 2010). Such vegetation facilitates the seepage process through the soil and the rocks beneath.

Cave fill material covers the floor of the cave. In order to understand the depth and nature of this cave fill material, core samples were collected. Small trenches were also dug to examine the sediments. The examined depth of the sediments varied from a maximum of $65 \mathrm{~cm}$ in the central part of the cave (near the entrance), gradually decreasing towards the northern end. Different layers in the sediment fill could be discerned; a top silt and mud layer (top soil) overlying silt embedded with rock fragments with a lower sandy silt layer resting on the lava floor. The size of the rock fragments ranged from boulder to pebble and clearly represent the collapsed part of ceiling. The silty and clayey nature of the sediment is suggestive of deposition in still or very slow moving water. Due to the high silt and mud content, the sediments exhibit cohesive properties.

A few small bone fragments were collected from the fine-grained cave sediments at $40 \mathrm{~cm}$ and $47 \mathrm{~cm}$ depth respectively. To ascertain the relative age of these bones, fluorine dating technique; a standard procedure in archaeological chemistry (Joshi, 2006-07) was carried out (Table 1). The procedure for this technique was developed by Carnot in 1892. He observed that there is a disparity in the concentration of the fluorine in the bones obtained from different environments. Fluorine has a strong affinity for the hydroxyapatite $\left[\mathrm{Ca}_{10}\left(\mathrm{PO}_{4}\right)_{6}(\mathrm{OH})_{2}\right]$, an inorganic phosphate material found in the bones. The hydroxyapatite acts as a natural trap for wandering fluoride ions occurring as traces in the groundwater and soils. The exchange of hydroxyl ions of hydroxyapatite with fluoride ions leads to the formation of Fluorapatite $\left[\mathrm{Ca}_{10}\left(\mathrm{PO}_{4}\right)_{6}(\mathrm{~F})_{2}\right]$, a stable mineral.

During the fossilization process, along with the fluorapatite, the agglomeration of other mineral matters may vary according to the respective environment. The phosphate measurement reveals the extent of contamination from the soil or other extraneous matter in the bone. The formula for fluorine dating is:

$$
\text { Ratio }=\frac{100 * \% \text { Fluorine }}{\% \text { Phosphorous pentoxide }}
$$

The fluorine/phosphate ratio is independent of the density of bone and therefore contamination problem is minimised. The percentage of phosphorous pentoxide $\left(\mathrm{P}_{2} \mathrm{O}_{5}\right)$ was determined from the percentage 
of phosphorous. The value of obtained phosphorous when multiplied with 2.21 gives the percentage of phosphorous pentoxide. The antiquity of the fossils can be determined by the high values of ratio while low values of ratio reveal contemporary fresh bones. The theoretical saturation value of this ratio is 8.92 (Table 2).

The ratios obtained for the present samples are 0.508 and 1.099. Based on the fluorine-phosphorous ratio it can be ascertained that the bone fragments range from mid to late Holocene period.

The cave cricket (Ceuthophilus) and bats (Rousettus leschenaulti) are the only fauna found in the cave. The cave crickets forage on the surface at night, returning to roost during the day. The bat species prefers to live in caves, where water is in the vicinity (Korad et al., 2007). Lichens are observed on the bare speleothem surfaces near the entrance zone.

Table 1. Result of Fluorine dating.

\begin{tabular}{|l|c|c|c|c|c|c|}
\hline Sr. No. & Depth & Material & $\begin{array}{c}\text { \% } \\
\text { Phosphate }\end{array}$ & $\begin{array}{c}\mathbf{\%}_{\mathbf{2}} \\
\mathbf{P}_{\mathbf{2}} \mathbf{O}_{\mathbf{5}}\end{array}$ & $\begin{array}{c}\mathbf{\%} \\
\text { Fluorine }\end{array}$ & $\begin{array}{c}\text { Ratio } \\
\text { (F/P) }\end{array}$ \\
\hline 1. & $40 \mathrm{~cm}$ & Bone & 10.5 & 23.62 & 0.12 & 0.508 \\
\hline 2. & $47 \mathrm{~cm}$ & Bone & 9.7 & 21.82 & 0.24 & 1.099 \\
\hline
\end{tabular}

Table 2. Fluorine /Phosphate ratio in fossilized bones from sites of different periods/ cultures and various region giving their approximate ages (Joshi 2006-07).

\begin{tabular}{|c|c|c|c|}
\hline Site/ Region & Period/ Culture & Approximate age & $100 \mathrm{~F} / \mathrm{P}_{2} \mathrm{O}_{5}$ \\
\hline $\begin{array}{l}\text { Site from Jammu and Kashmir, } \\
\text { Andhra Pradesh, Karnataka, } \\
\text { Madhya Pradesh and Maharashtra }\end{array}$ & late Holocene & 500 - 2000 B.C. & $<1$ \\
\hline $\begin{array}{l}\text { Moti Pipali (Gujarat) and Phalodi } \\
\text { (Rajasthan) }\end{array}$ & $\begin{array}{l}\text { mid Holocene to terminal } \\
\text { Pleistocene }\end{array}$ & $2500-6000$ B.C & $1-2$ \\
\hline $\begin{array}{l}\text { Mundur (Karnataka) and Kurnool } \\
\text { caves (Andhra Pradesh) }\end{array}$ & $\begin{array}{l}\text { early Holocene to upper } \\
\text { Palaeolithic }\end{array}$ & $7 \mathrm{ka}-10 \mathrm{ka}$ & $2.10-3.70$ \\
\hline $\begin{array}{l}\text { Kalpi (Yamuna cliff), } \\
\text { Manjra and Ghod (Maharashtra) }\end{array}$ & $\begin{array}{l}\text { upper Palaeolithic/ } \\
\text { upper Pleistocene }\end{array}$ & $10 \mathrm{ka}-20 \mathrm{ka}$ & $3-5$ \\
\hline $\begin{array}{l}\text { Belghat (Narmada valley), } \\
\text { Kalegaon and Nevasa } \\
\text { (Maharashtra) }\end{array}$ & $\begin{array}{l}\text { upper Pleistocene/ } \\
\text { middle Palaeolithic }\end{array}$ & $20 \mathrm{ka}-40 \mathrm{ka}$ & $4.24-6$ \\
\hline $\begin{array}{l}\text { Hathnora and Gowarighat } \\
\text { (Narmada valley) }\end{array}$ & $\begin{array}{l}\text { late middle Pleistocene/ } \\
\text { middle and lower } \\
\text { Palaeolithic }\end{array}$ & $>40 \mathrm{ka}$ & $7.70-8.15$ \\
\hline Hunsgi valley, Chirki, Nevasa & $\begin{array}{l}\text { mid Pleistocene/ } \\
\text { acheulian }\end{array}$ & $0.1 \mathrm{Ma}-0.2 \mathrm{Ma}$ & $6.73-8.39$ \\
\hline Bor, Siwalik fossils & $\begin{array}{l}\text { lower Pleistocene/ } \\
\text { acheulian }\end{array}$ & $0.7 \mathrm{Ma}-1.8 \mathrm{Ma}$ & $6.66-8.45$ \\
\hline Kutch (Tertiary fossil) & Tertiary period & - & $8.15-9.42$ \\
\hline Theoretical saturation value & - & - & 8.92 \\
\hline
\end{tabular}

\section{DISCUSSION}

When discussing the genesis of lava caves in DVP, it is important to consider the nature of the flow in which it is observed and also its emplacement mechanism. Besides, in a $65 \mathrm{Ma}$ dissected lava provinces, the extent of exhumation should also be taken into consideration. The lava cave reported from Ghoradeshwar, occurs in a small isolated hill. The flow units exposed in other isolated hills in the adjacent area belong to the same litho-stratigraphic unit, but extension of the cave is not seen. The lava flow which hosts the natural cave is a compound pāhoehoe flow with small toes, lobes and sheet lobes that exhibit laterally inter-fingering relationship with small scale features like squeeze-ups. Flow lobes and toes develop gradually from flow sheet lobes by continuous supply of lava to the advancing front (Lockwood and Hazlett, 2010). These are comparable to the inflation layers described by Kempe (2013). Importance of inflated pāhoehoe sheets in emplacement of DVP have been discussed by a few workers (e.g., Keszthelyi et al., 1999; Bondre et al., 2000). Based on the surface features and comparing it with other compound pāhoehoe flows from Maharashtra, we presume that the emplacement of these pāhoehoe flows has been by inflation and continual budding of the advancing lava lobes, similar to the mechanism described by Duraiswami et al. (2004).

As described earlier, the lava cave has a broad sinuous/meandering outline with openings to the north and south that open into the central chamber, where the present cave entrance is seen. Downward erosion or thermal erosion was not observed in the lava cave. Towards the upper part of the cave, near the ceiling, the reddened glassy crust that separates the older (flow unit) flow lobe is seen. The cave is thus seen only in the lower pāhoehoe flow (sheet lobe), within a single (flow unit) flow lobe. Covered conduits can form within a single thick flow unit (Harter, 2009). Pyroducts are known to develop beneath inflating crusts on gentler slopes (Lockwood and Hazlett, 2010). The importance of pyroducts for the transport of lava where topography is gentle is well demonstrated by the Hashemite University cave, found in the Quaternary flow field of the Qais/Makais Volcanoes (Al-Malabeh and Kempe, 2012). The dimensions of the cave explored at Ghoradeshwar, are small compared to 
the major conduits/pyroducts described from other volcanic fields, but are morphologically comparable with inflated lobes. The small blister caves reported as tunnels by earlier workers (Kulkarni and Gaikwad, 1984; Phadke and Ghate, 1984) are also from Pune. From this, it is apparent that the gentle topography around Pune controlled the progression of lava in this lava field. Further, the gentle micro-topography at Ghoradeshwar controlled the advancement of pāhoehoe lobes and toes within the sheet lobe. It is possible that the progression of flow was from the east, where the cave opening is presently seen. The moderate gradients controlled the lava flow which advanced in the southern and northern direction. The portion of the cave, near the entrance where cave fill material is seen, could have developed a small plunge pool.

The cross sectional pattern of the lava cave along the $20 \mathrm{~m}$ passage mostly varies from circular to semicircular, with a small portion exhibiting a gothic shape. The gothic shape could have resulted from the escape of gas leading to modification of the ceiling along the median part when the lava had not completely solidified. From the dimensions and related morphology it would be appropriate to categorize the present cave as a small sub-crustal cave, formed by draining of an inflated pāhoehoe lava lobe (flow unit). The drained flow lobes may have interconnected forming a conduit of smaller dimension as seen in the area.

According to Rajaguru and Misra (1997), the last glacial period is well documented in many parts of India and many of the rivers were aggrading between 12-18 ka. The early Holocene (9-6 ka) was a period of good monsoon in India, when black soil developed over the aggraded alluvial plains in the Deccan plateau. The speleothem deposits seen in the cave can be related to the early Holocene humid phase, when intensification of monsoons took place. Fluorine dating of the bones retrieved from the sediments indicates mid to late Holocene age of the sediments. Archaeologically, the cave contents are young, but it is difficult to ascertain the exact age of exposure of the cave opening.

\section{CULTURAL ASPECT}

In India, natural caves have been occupied by Stone Age man in Madhya Pradesh, Andhra Pradesh and Maharashtra. There are nearly 1550 rock cut caves in India, of which 1200 are located in Maharashtra. The tradition of carving temple in the rocks began with Buddhist shrines in the $1^{\text {st }}$ and $2^{\text {nd }}$ centuries BC (Patel, 2007). The fundamental objective of these caves was to serve as Buddhist chapel and monasteries (Ray, 1988) and were located along the principal trade routes, specially connecting the ports to market towns of the interior (Dehejia, 1969).

At Ghoradeshwar, there are a few Buddhist caves carved in pāhoehoe lava flows at an elevation of about $760 \mathrm{~m}$ and those occur in the same flows in which the lava cave is observed. These caves belonged to Hinayana doctrine of Buddhism, in which the Buddha was worshipped only through symbols such as stupa. It is interesting to note that most of the rock cut caves reported from Maharashtra, in Deccan Volcanic Province are from pāhoehoe flows. This includes the rock cut caves of world heritage sites of Ajanta and Ellora. At Ellora, Ansari et al. (2014) have indicated the presence of a lava conduit very close to the cave 32. This in all probability indicates that early man took advantage of the existing openings in pāhoehoe flows and sculpted the caves to suit their requirements. Lava caves are known to have served as homes and temporary shelters throughout history and are significant archaeological sites.

\section{ACKNOWLEDGEMENT}

The Authors thank Shri. G. R. Kulkarni, Retired Geologist, for his constructive suggestions in the field and Shri Natraj Vaddadi for critically going through the manuscript. The encouragement and guidance of Dr. Ken Grimes, Consulting Geologist, was extremely useful in shaping this paper. The authors gratefully acknowledge his help. The authors also thank the reviewers for painstakingly going through the manuscript and giving valuable suggestions that has helped in improving the quality of the paper.

\section{REFERENCES}

Al-Malabeh A. \& Kempe S., 2012 - Hashemite University Cave, Jordan. - Abstracts and Proceedings 15th Intern. Symp. on Vulcanospeleology, Hashemite Univ. Zarka Jordan, 15-22 March, 2012: 43-48.

Ansari M.K., Ahmad M. \& Singh T.N., 2014 - Rockfall hazrd analysis of Ellora cave, Aurangabad, Maharashtra, India. International Journal of Science and Research, 3 (5): 427-431.

Atkinson A., Griffin T.J. \& Stephenson P.J., 1975 - A major lava tube system from Undara Volcano, North Queesnsland. Bulletin of Volanology, 39: 1 - 38. http://dx.doi.org/10.1007/BF02597832

Bondre N.R., Dole G., Phadnis V.M., Duraiswami R.A. \& Kale V.S., 2000 - Inflated pāhoehoe lavas from the Sangamner area of the western Deccan Volcanic Province. Current Science, 78: 1004-1007.

Carnot C.A., 1892. Researches on fluorine in modern bone and in fossil bone. Compt. Rend. Acad.Sci. 144: 1189-1192.

Coan T., 1844 - "Journey to Mauna Loa." Missionary Herald, 40, February, 44-7; In Lockwood O.P. \& Hazlett R.W. (Eds.), Volcanoes Global Perspective. Wiley Blackwell, UK., p. 541.

Dehejia V., 1969 - Early Buddhist caves at Junnar. Artibus Asiae, 31 (2-3): 147-166.

Duraiswami R.A., Bondre N.R. \& Dole G., 2004 - Possible lava tube system in a hummocky lava flow at Daund, western Deccan Volcanic Province, India. Proceedings of Indian Academy of Science, 113 (4): 813-829.

Godbole S.M., Rana R.S. \& Natu S.R., 1996 - Lava stratigraphy of Western Maharashtra. Gondwana Geological Society Magazine, Special Publication, 2: $125-135$.

Greeley R., 1971 - Geology of the selected lava tubes in the Bend area. State of Oregon, Department of Geology and Mineral Industries, Bulletin, $47 \mathrm{p}$.

Greeley R., 1987 - The role of lava tubes in Hawaiian volcanoes. United States Geological Survey, 1350: 1584-1602. 
Grimes K.G., 2002 - Small subcrustal drainage lava caves; examples from Victoria, Australia. In: Espinasa R. \& Pint J. (Eds.), Proceedings of the $10^{\text {th }}, 11^{\text {th }}$, and $12^{\text {th }}$ International Symposia on Volcanospeleology, 19: 35-44.

Grimes K.G., 2005 - Lava tube formation. Regolith Mapping, 1 (1): 1-4.

Halliday W.R., 2002 - What is a lava tube? AMCS Bulletin 19 / SMES Boletín 7: 48 - 56.

Harter R., 2009 - Pisgah! Western Region, National Speleological Society - Speleo-Ed Seminar, Rainbow Basin - Barstow, California - March 20-22, 2009: 24-35.

Hon K., Kauahikaua J., Denlinger R. \& Mackay K., 1994 - Emplacement and inflation of pāhoehoe sheet flows: observations and measurements of active lava flows on Kileauea Volcano, Hawaii. Bulletin of Geological Society of America, 106: 351-370.

http://dx.doi.org/10.1130/0016-7606(1994)106 $\leq 0351$ :EAIOPS $>2.3 . \mathrm{CO} ; 2$

Hooper P., Widdowson M. \& Kelley S., 2010 - Tectonic setting and timing of the final Deccan flood basalt eruptions, Geology, 38 (9): 839-842. http://dx.doi.org/10.1130/G31072.1

Joshi S.V., 2006-07 - Fluorine dating of the Pleistocene vertebrate fossils from Siwaliks, Himachal Pradesh. Bulletin of the Deccan College Post Graduate and Research Institute, Pune, 66-67: 285-289.

Kale V.S. \& Kulkarni H., 1992. - IRS-1A and LANDSAT data in mapping Deccan trap flows around Pune, India: Implication of hydrogeological modelling. Archives of International Society Photogrammetry and Remote Sensing, 29: 429-435.

Kempe S., Bauer I., Bosted P., Coons D. \& Elhard R., 2010 - Inflationary versus crusted-over roofs of pyroducts (lava tunnels). In: Middleton G.J. (Ed.), Proceedings of the $14^{\text {th }}$ International Symposium on Vulcanospeleology, International Union of Speleology Commission on Volcanic Caves, Queensland: 93-102.

Kempe S., 2013 - Morphology of speleothems in primary (lava-) and secondary caves. In: Shroder J.F. \& Frumkin A. (Eds.), Treatise on Geomorphology, Karst Geomorphology, San Diego, 6: 267-285.

Keszthelyi L. \& Self S., 1998 - Some physical requirements for emplacement of long basaltic flows. Journal of Geophysical Research, 103: 27447-27464. http://dx.doi.org/10.1029/98JB00606

Keszthelyi L., Self S. \& Thordarson T., 1999 - Application of recent studies on the emplacement of basaltic lava flows to the Deccan Traps. In Subbarao K.V. (Ed.), Deccan Volcanic Province, Memoir of Geological Society of India: 43: 485-520.

Korad V., Yardi K. \& Raut R., 2007 - Diversity and distribution of bats in the Western Ghats of India. Zoos' Print Journal, 22: 2752-2758.

http://dx.doi.org/10.11609/JoTT.ZPJ.1563.2752-8

Kulkarni G.R. \& Gaikwad L.D., 1984 - Geology of PuneKhed area, Pune district, Maharashtra. Geological Survey of India, Special Publication. 14: 29-32.
Lockwood O.P. \& Hazlett R.W., 2010 - Volcanoes global perspective. Wiley Blackwell, UK.541.

Misra K.S., 2002 - Arterial system of lava tubes and channels within Deccan volcanics of western India. Journal Geological Society of India, 59: 115-124.

Patel S.S., 2007 - The Slum and the Sacred cave. Archaeology, 60 (3): 38-44.

Peterson D.W. \& Swanson D.A., 1974 - Observed formation of lava tubes during 1970-71 at Kilauea Volcano, Hawaii, Studies in Speleology, 2 (6): 209-222.

Phadke A.V. \& Ghate N.S., 1984 - The Occurrence of lava tunnels in pāhoehoe basalt flows of Pune area. Geological Survey of India, Special Publication, 14: 18-19.

Rajaguru S.N. \& Mishra. S., 1997 - Late Quaternary climatic changes in India: A geoarchaeological approach. Indo-Pacific Prehistory association Bulletin, 16: 27 -32.

Ray H., 1988 - Early Buddhist caves of the western Deccan - Indian long-distance trade in the early centuries A.D. Expedition, 30 (2): 3-9.

Sen B., Sabale A.B. \& Sukumaran P.V., 2012 - Lava channel of Khedrai Dam, Northeast of Nasik in Western Deccan volcanic province: Detailed morphology and evidences of channel reactivation. Journal of Geological Society of India, 80: 314-328. http://dx.doi.org/10.1007/s12594-012-0150-8

Sharma R.K. \& Vaddadi S., 1996 - Report on lava tubes/ channels from Deccan Volcanic Province. Gondwana Geological Society Magazine, Special Publication, 2: 457-460.

Simons J.W., 1998 - Volcanic caves of Kenya, a guide; $8^{\text {th }}$ International Symposium, Vulcanospeleology, 37p.

Subbarao K.V. \& Hooper P.R., 1988 - Reconnaissance map of the Deccan Basalt Group in the Western Ghats, India. In: Deccan Flood Basalts, Memoir Geological Society of India, No.10.

Thorat P.K., 1996 - Occurrence of lava channels and tubes in the western part of Deccan Volcanic Province. Gondwana Geological Society Magazine, Special Publication, 2: 449-456.

Verachtert E., Van Den Eeckhaut M., Poesen J. \& Deckers J., 2010 - Factors controlling the spatial distribution of soil piping erosion on loess-derived soils: A case study from central Belgium. Geomorphology, 118: 339-348. http://dx.doi.org/10.1016/j.geomorph.2010.02.001

Waltham A.C. \& Park H.D., 2002 - Roads over lava tubes in Cheju Island, South Korea. Engineering Geology, 66: 53-64.

http://dx.doi.org/10.1016/S0013-7952(02)00030-3

Waters A.C., Donnelly-Nolan J.M. \& Rogers B.W., 1990 Selected caves and lava-tube systems in and near Lava Beds National Monument, California; USGS Bulletin 1673.

Widdowson M., 1997 - Tertiary palaeosurfaces of the SW Deccan, Western India: implications for passive margin uplift. Geological Society Special Publications, 120: 221-248.

http://dx.doi.org/10.1144/GSL.SP.1997.120.01.15 